\title{
Population dynamics and habitat selection of the European hare on poplar monocultures in northern Italy
}

\author{
Alberto MERIGGI and Annalisa VERRI
}

\begin{abstract}
Meriggi A. and Verri A. 1990. Population dynamics and habitat selection of the European hare on poplar monocultures in northern Italy. Acta theriol. 35: 69-76.

Drive censuses were carried out in March and November of each year from 1981 to 1987 to assess the spring and autumn densities of European hare Lepus europaeus Pallas, 1778, in a protected area ( 375 ha) covered with poplar groves in the middle Po plain (northern Italy). Besides, line-transect censuses were made in 1986 and 1987 to record seasonal changes in density. Habitat selection was studied by comparing densities of resting hares and the frequency of observation of hares in activity in different habitats. The average recorded densities were 52.6 hares $/ \mathrm{km}^{2}(\mathrm{SD}=35.97)$ in spring and $38.1(\mathrm{SD}=16.57)$ in autumn. The anomalous annual trend characterised by decreases from spring to autumn and increases from autumn to spring was explained by changes in food availability, which cause movements towards other zones surrounding the study area. The estimates of seasonal density showed that the decrease begins in late summer and will continue till late winter. The analysis of the habitat preferences showed a separation between feeding areas and resting areas.

Dipartimento di biologia Animale, Università di Pavia, Piazza Botta 9-27100 Pavia, Italy

Key words: census, Lepus europaeus, Italy, habitat selection, food availability
\end{abstract}

\section{Introduction}

The ecology of the European hare, Lepus europaeus Pallas, 1778, is well known in the northern parts of its European range. The situation is quite different for southern Europe, and for Italy, only few researches have been published so far (Prigioni and Pelizza 1988, in print, Meriggi et al. 1988, Meriggi and Alieri, in print).

It has already been stated by Bresiński (1976a), Pepin (1978), Frylestam (1981a, 1986), Kovacs and Healtay (1981), Tapper and Barnes (1986), that the changes induced by modern agricultural methods influence the ethology and ecology of the species. In the present work we have examined the population dynamics and habitat selection of the hares in a fluvial area of the Po-plain, mainly cultivated with poplar plantations.

\section{Study area}

The study area ( 396 ha) is situated in the middle of the Po-plain in a high-water bedded zone where the Po and Ticino rivers join. This zone has been prohibited to hunters since 1975. In some years this area is partially flooded by the two rivers in spring and autumn. The climate is continental to moderate sublitoral, with an annual average temperature of $12.3^{\circ} \mathrm{C}$ and $803 \mathrm{~mm} /$ year of rainfall concentrated in spring and autumn.

The area is covered with monocultures, mainly poplar plantations $(82.8 \%)$ and only a small part 
$(6.5 \%)$ is used for crops (maize, wheat and lucerne) common in the Po-plain. Spontaneous vegetation, which is limited to the riverside, embankments and to some uncultivated fields, decreased from $13.1 \%$ in 1981 to $9 \%$ in 1987 . In poplar plantations many herbaceous species are present, mainly Solidago gigantea, Urtica dioica, Lamium purpureum, Agropyron repens, Setaria glauca, Chenopodium album, Polygonum hydropiper and Polygonum lapathifolium.

These poplar plantations can be classified in three classes according to the age of the trees:

(a) poplars from 1 to 3 years, in which maize and wheat can be grown because of the limited canopy cover;

(b) poplars from 4 to 7 years, which are periodically harrowed in spring and summer;

(c) poplars from 8 to 11 years, which get harrowed once a year but not sufficient for a control of herbaceous plants and shrubs, i.e.: Amorpha fructicosa, Rubus sp., Cornus sanguinea and Robinia pseudoacacia.

\section{Methods}

The changes in size of the hare population were studied from 1981 to 1987 by drive censuses in March and November of each year. In 1986 and 1987 sample counts were made by line transects from vehicles (6 every season), in order to record the seasonal variations in density following the methods suggested by Burnham et al. (1980), Smith (1981) and Gogan et al. (1986). The estimates of the seasonal density were obtained applying the following formula (Overton 1971):

$$
D=2 D_{(\mathrm{K})}-D_{(\mathrm{K}-1)}
$$

where $D_{(\mathrm{K})}$ is the highest density value of all the line transects completed in a given season, and $D_{(\mathrm{K}-1)}$ is density value immediately below.

The habitat choice for daytime resting of the hares was studied by comparing the densities recorded in different habitats by strip-censuses. For this method of census, the formula given by Pepin and Birkan (1981) was used:

$$
N=n_{2}+n_{1} \times \frac{W}{2 E(B-1)}
$$

where $N$ is the number of hares in the strip, $n_{1}$ is the number of hares found within the minimum escape distance, $n_{2}$ is the number of hares found beyond the minimum escape distance, $W$ is the width of the strip, $E$ the minimum escape distance and $B$ the number of beaters.

To define the patterns of habitat selection for feeding activity, observations were made on feeding hares, during the first and last hours of daylight. Chi-square test was used to identify significant differences between the seasonal values of use and availability of different habitat types. When $\chi^{2}$ rose to significant values $(p<0.05)$, simultaneous Bonferroni confidence intervals were calculated for proportions of usage of every habitat type (Neu et al. 1974, Byers et al. 1984) by the following formula:

$$
P_{\mathrm{i}}-Z_{x / 2 \mathrm{~K}} \sqrt{P_{\mathrm{i}}\left(1-P_{\mathrm{i}}\right) / n}<P_{\mathrm{i}}<P_{\mathrm{i}}+Z_{x / 2 \mathrm{~K}} \sqrt{P_{\mathrm{i}}\left(1-P_{\mathrm{i}}\right) / n}
$$

where $n$ stays for the total number of observations, $P_{\text {i }}$ is the proportion of usage observed for the $i$ th type of habitat, $Z$ is the upper standard normal table value corresponding to a probability tail area of $\alpha / 2 \mathrm{~K}$ with $\alpha=0.05$ and $K=$ the number of different types of habitat considered. When the expected proportion of usage fell out of the estimated interval, the difference between the expected and observed utilization rate was considered significant. 


\section{Results}

Densities and numerical changes

From 1981 to 1987, large fluctuations in the density were recorded (Fig. 1), with a tendency to increase until spring 1984, while in the subsequent years the densities decreased to the starting levels. As a whole the hare population did not show a regular trend, because substantial decreases were recorded from spring to autumn $(10.4 \%$ average), and increases between autumn and spring censuses ( $46.4 \%$ average). Annual recruitments were recorded only in 1981,1983 and $1986(31.3 \%$, on average for the 3 years), and winter mortality only in 1982 and $1983(27.1 \%)$.

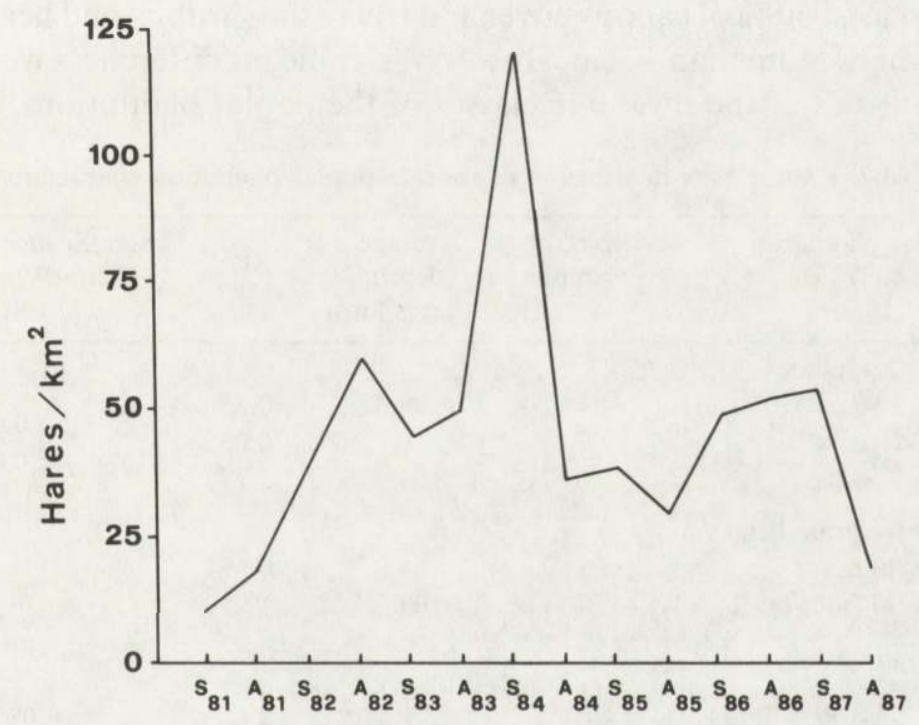

Fig. 1. Changes in the hare population density from spring (S) 1981 to autumn (A) 1987.

The spring density $\left(\bar{x}=52.6\right.$ hares $\left./ \mathrm{km}^{2}, \mathrm{SD}=35.97\right)$ was negatively correlated with the amount of total rainfall of the previous year $(r=-0.968, p<0.01)$, and with the rainfall of December $(r=-0.998, p<0.001)$. Positive correlations were found with the

Table 1. Seasonal changes of the hare density (hares $/ \mathrm{km}^{2}$ ).

\begin{tabular}{clc}
\hline Year & Season & Density estimate \\
\hline 1986 & Spring & 20.2 \\
& Summer & 31.0 \\
& Autumn & 10.5 \\
& Winter & 9.7 \\
1987 & Spring & 25.7 \\
& Summer & 26.4 \\
& Autumn & 12.8 \\
\hline
\end{tabular}
rainfalls in February $(r=0.931, p<0.05)$. The autumn density $\left(\bar{x}=38.1\right.$ hares $\left./ \mathrm{km}^{2}, \mathrm{SD}=16.57\right)$ was positively correlated with the rainfalls in July $(r=0.895, p<0.02)$. The annual recruitement was negatively correlated with rainfalls in September and October $(r=0.906, p<0.05$ and $r=0.93, p<0.05$ ) and with the amount of rainfalls from January to October $(r=0.997$, $p<0.001)$.

The intercurrent numerical changes between 
November and March of the following year did not seem to be dependent on clinatic factors. No significant correlation was found between the temperatures and dersities or numerical variations.

In 1986 and 1987 the seasonal densities (Table 1) increased from spring to summer, then decreased remarkably in autumn, and even more in winter, when the lowest seasonal densities were recorded.

\section{Habitat selection}

It seems that in the area studied the hares select their resting site in relation to the vegetation structure (Table 2). The highest densities of sheltering hares were recorded in areas with at least $50 \%$ of canopy cover and where the shrubby and herbaceouslayer reached a height of more than $40 \mathrm{~cm}$. However, significant differences were found only among the densities of the three age classes of the poplar plantations.

Table 2. Resting hare densities in relation to poplar plantation characteristics.

\begin{tabular}{|c|c|c|c|c|}
\hline $\begin{array}{l}\text { Poplar plantation } \\
\text { characteristics }\end{array}$ & $\begin{array}{c}\text { No. of } \\
\text { samples }\end{array}$ & $\begin{array}{c}\text { Average } \\
\text { density } \\
\text { (hares } / \mathrm{km}^{2} \text { ) }\end{array}$ & SD & $\begin{array}{c}\text { Significance level } \\
\text { Mann-Whitney } \\
\text { U test }\end{array}$ \\
\hline Age of poplars & & & & \multirow{4}{*}{$\begin{array}{l}p<0.02 \\
p<0.02\end{array}$} \\
\hline $1-3$ years & 4 & 89.6 & 0.65 & \\
\hline 4-7 years & 7 & 9.7 & 0.25 & \\
\hline$>7$ years & 6 & 160.9 & 2.19 & \\
\hline \multicolumn{5}{|c|}{ Avarage grass height } \\
\hline$\leqslant 40 \mathrm{~cm}$ & 8 & 64.9 & 0.69 & \multirow{2}{*}{ ns } \\
\hline$>40 \mathrm{~cm}$ & 9 & 109.0 & 1.91 & \\
\hline \multicolumn{5}{|l|}{ Canopy cover } \\
\hline$\leqslant 50 \%$ & 11 & 57.1 & 0.63 & \multirow{2}{*}{ ns } \\
\hline$>50 \%$ & 6 & 136.7 & 2.28 & \\
\hline \multicolumn{5}{|l|}{ Shrub stratum } \\
\hline present & 10 & 116.1 & 1.80 & \multirow{2}{*}{ ns } \\
\hline absent & 7 & 49.6 & 0.65 & \\
\hline \multicolumn{5}{|c|}{ Average shrub height } \\
\hline$\leqslant 1 \mathrm{~m}$ & 3 & 74.7 & 0.72 & \multirow{2}{*}{ ns } \\
\hline$>1 \mathrm{~m}$ & 7 & 136.7 & 2.15 & \\
\hline
\end{tabular}

Hares, in activity (579 observations in the two years) did not show particular seasonal preferences for the different types of habitats in the study area: the comparison between the expected and the observed frequencies gave significant results in spring and summer only, when the Bonferroni statistics have shown that the natural vegetation in both season, and the habitat with poplars over 7 years old were poorly frequented in summertime (Table 3).

In autumn and winter the hares did not seem to make any choice of habitat as the differences between proportion of usage and availability are not significant 
Table 3. Habitat preferences of feeding hares (E.P.U.=Expected proportion of usage; O.P.U. $=$ Observed proportion of usage; ${ }^{*}$ differences at 0.05 significance level).

\begin{tabular}{lcccccc}
\hline Habitat & \multicolumn{2}{c}{$\begin{array}{c}\text { Spring 1986 } \\
(\mathrm{N}=94)\end{array}$} & \multicolumn{2}{c}{$\begin{array}{c}\text { Summer 1986 } \\
(\mathrm{N}=207)\end{array}$} & \multicolumn{2}{c}{$\begin{array}{c}\text { Spring 1987 } \\
(\mathrm{N}=82)\end{array}$} \\
& E.P.U. & O.P.U. & E.P.U. & O.P.U. & E.P.U. & O.P.U. \\
\hline $\begin{array}{l}\text { Poplar plantations: } \\
\quad \text { 1-3 years old }\end{array}$ & 0.116 & 0.225 & 0.103 & 0.142 & 0.236 & 0.333 \\
$\quad$ 4-7 years old & 0.386 & 0.466 & 0.386 & 0.349 & 0.267 & 0.202 \\
$\quad>7$ years old & 0.155 & 0.100 & 0.155 & $0.100^{*}$ & 0.280 & 0.357 \\
Natural vegetation & 0.116 & $0.025^{*}$ & 0.166 & $0.089^{*}$ & 0.126 & $0.047^{*}$ \\
Crops & 0.187 & 0.183 & 0.187 & 0.317 & 0.087 & 0.059 \\
$\chi^{2}$ & \multicolumn{2}{c}{10.28} & \multicolumn{2}{c}{30.98} & \multicolumn{2}{c}{10.28} \\
Significance & \multicolumn{2}{c}{$p<0.05$} & \multicolumn{2}{c}{$p<0.0001$} & \multicolumn{2}{c}{$p<0.05$} \\
\hline
\end{tabular}

\section{Discussion}

Densities and numerical changes

The densities recorded in the study area in spring and autumn are comparable to those found in north and central Europe, though in very different environmental conditions (Jezierski 1968, Rajska 1968, Bresiński 1976b, Bresiński and Chlewski 1976, Pepin and Birkan 1981, Frylestam 1981a, Barnes et al. 1983, Swihart 1986). The recruitment of population and the winter mortality appear on the contrary very different. From the seasonal densities recorded in the study area in 1986 and 1987, it seems that the decrease begins in late summer and continues until late winter; later, the population size increases between late winter and early spring. Therefore the study area seems to have a greater carrying capacity in spring than in autumn. Most of the numerical changes may be due to migration and immigration, which in turn could be a consequence of the type of vegetation in the area. Actually, in the large extensions of a single-crop such as the poplar plantations (more than $90 \%$ of the area), the hare can find plenty of good quality food, especially in late winter and early spring when the underwood grasses are growing (Frylestam 1976). The frequent harrowing of the poplar plantations in summer helps the grass to grow very quickly, as a consequence of soil moisture and high temperatures. After August harrowing, at the onset of autumn, when the temperature in the air drops, the grasses grow very slowly, and the total area available for feeding is reduced. In this period the hares may migrate to other zones surrounding the study area, where wheat, maize and lucerne are cultivated extensively (Frylestam 1981b).

During late autumn and winter the dispersion of the hares seems to be dependent on population density. The described trend was more evident from 1984 to 1987 parallel to the tendency toward a decrease, in the population which is followed by the maximum size reached in the spring of 1984 . When hare density is high and the feeding grounds are limited, the hares tend to get aggressive and become hierarchical, in 
relation to their body size (Lindlof 1978, Monaghan and Metcalfe 1985). Also in Lepus americanus (Boutin 1984) the aggressive behaviour on feeding areas was found to induce dispersion of the young hares and a decline of the population size.

In our work the correlations found between densities and climatic variables correspond to other literature data (Puppe 1966, Möller 1967, Bresiński 1976b, Spittler 1976, Birkan and Pepin 1984).

The rainfall generally has a negative influence except in February and July. Thus, rainfalls in February and increasing temperatures in March will induce an early growth of grasses. In northern Italy July is the driest month of the year and, because of that, rainfall can favour the regrowth of grasses in the poplar plantations after harrowing in summer. A positive influence of the rain on the survival of the young hares has been observed also in Poland, in areas of steppe vegetation where the climate is particularly dry in the summer (Bresiński 1976b).

In our case the temperature does not seem to have any positive or negative influence on the hares population, probably as a consequences of the limited thermal range of the climate, as shown by the average temperature during winter which seldom drops under $0^{\circ} \mathrm{C}$.

\section{Habitat selection}

The densities of resting hares recorded in different types of vegetation, show that in general hares prefer mature poplar plantations with a high canopy cover and shaded ground. For daytime, resting places with dense and high grasses and bushes are choosen. Frylestam (in: Tapper and Barnes 1986) thinks that woody habitats offer protection against bad weather and predators: the tree foliage would protect the hares from birds of prey, and a dense underwood vegetation would make it difficult for the terrestrial predators to reach them. Such preferences are also conditioned by the seasons: the high vegetation is preferred during the hot summer days, and during periods of low temperatures in winter (Tapper and Barnes 1986).

When in activity, hares select types of habitat of the opposite kind. In spring, the only type of poorly used habitat is the wild vegetation. In this season, the grasses which grow in the poplar plantations of all age are important for feeding. In summer the wild vegetation, and the old poplar plantations are frequented less than expected, in relation to their availability. Underneath mature poplar-woods, which get harrowed less than younger and middle-aged poplars plantations, a dense, bushy herbaceous undergrowth is present which is not attractive for the hares because the lack of tasty grasses. In autumn, and especially in winter, the hares do not show particular preferences, and use any type of habitat available including the wild vegetation.

Some authors reported that hares prefer open environments with herbaceous vegetation in growth for feeding. Such behaviour is due to the fact that they need not only a good quality of food but also the possibility to be aware of and escape from predators (Hewson and Taylor 1968, Frylestam 1976, 1981b, Tapper and Barnes 1986). 


\section{Conclusions}

A fairly uniform environment, e.g. the poplar plantations considered in our study, may induce important changes in the hare ecology and ethology. At the end of the breeding season recruitment is cancelled by migration and mortality, dependent on the environment features. Thus losses are apparent at the beginning of autumn rather than in winter.

After a decrease in population density from September to February, the breeding population is rebuilt due to immigration when habitat conditions became more favourable in early spring. In order to get food of good quality, in all seasons, the hares change their living habitat (Tapper and Barnes 1986) owing to the impossibility of extending the home range, as well as a size typical for the species (Swihart 1986, Kovacs and Buza, in print). Areas with single crops of any type offer plenty of food in some periods of the year, but a very much reduced amount in other periods. In this environmental situation the populations are not steady but subjected to fluctuations during the annual cycle and over periods of many years mainly due to migrations to more favourable areas. The analysis of the environmental preferences found in our study has shown a separation between feeding areas, and resting areas a typical behavioural characteristic of the species:

\section{References}

Barnes R. F. W., Tapper S. C. and Williams J. 1983. Use of pastures by Brown hares. J. Appl. Ecol. 20: $179-185$.

Birkan M. and Pepin D. 1984. Tableaux de chasse et de piégeage d'un meme territoire entre 1950 et 1971 : Fluctuation numériques des espèces et facteurs de l'environnement. Gibier Faune Sauvage 2: 97-111.

Boutin S. A. 1984. The effect of conspecifics on juvenile survival and recruitment of Snowshoe hares. J. Anim. Ecol. 53: 623-637.

Bresiński W. 1976a. Agrarian structure vs. the European hare population density. [In: Ecology and management of European hare populations, Z. Pielowski and Z. Pucek, eds]. Warszawa: 195-197.

Bresiński W. 1976b. Weather conditions vs. European hare population dynamics. [In: Ecology and management of European hare populations Z. Pielowski and Z. Pucek, eds]. Warszawa: 105-110.

Bresiński W. and Chlewski A. 1976. Tree stands in fields and spatial distribution of hare populations [In: Ecology and management of European hare populations Z. Pielowski and Z. Pucek, eds]. Warszawa: $185-193$.

Burnham K. P., Anderson D. R. and Laake J. L. 1980. Estimation of density from line transect sampling of biological populations. Wildl. Monogr. 72: 1-202.

Byers C. R., Steinhorst R. K. and Kransman P. R. 1984. Clarification of a technique for analysis of utilization-availability data. J. Wildl. Manage. 48: 1050-1053.

Frylestam B. 1976. Effects of cattle-grazing and harvesting of hay on density and distribution of an European hare populations. [In: Ecology and management of European hare populations, Z. Pielowski and Z. Pucek, eds]. Warszawa: 199-203.

Frylestam B. 1981a. Estimating by spotlight the population density of the European hare. Acta theriol. 26: $419-427$.

Frylestam B. 1981b. Utilization of farmland habitats by European hares (Lepus europaeus P.) in Southern Sweden. Viltrevy 6: $271-284$. 
Frylestam B. 1986. Agricultural land use effects on the winter diet of Brown hares (Lepus europaeus P.) in Southern Sweden. Mammal Rev. 16: 157-161.

Gogan P. J. P., Thompson S. C., Pierce W. and Barrett R. M. 1986. Line transect censuses of fallow and black-tailed deer on the Point Reyes peninsula. Calif. Fish and Game 72: 47-61.

Hewson R. and Taylor M. 1968. Movements of European hares in an upland area of Scotland. Acta theriol. 23: $31-34$.

Jezierski W. 1968. Some ecological aspects of introduction of European hare. Acta theriol. 23: 1-30.

Kovacs G. and Buza C. S. (in print) Home-range size of the Brown Hare in Hungary. XVIIIth I.U.G.B. Congress, Kraków, Poland.

Kovacs G. and Heltay I. 1981. Study of a European hare population mosaic in the Hungarian lowland. [In: Proc. World Lagomorph Conf., K. Myers and C.D. Mac Innes, eds]. Guelph, Ontario: 508-528.

Lindlof B. 1978. Aggressive dominance rank in relation to feeding by European hare. Viltrevy 10: 146-157.

Meriggi A. and Alieri R. (in print) The influence of environmental variables on the density of hares in protected areas of North Italy. XVIIIth I.U.G.B. Congress, Kraków, Poland.

Meriggi A., Prigioni C., Bogliani G., Barbieri F. and Fasola M. 1988. Censimenti di fagiani e lepri in provincia di Pavia. Atti I Sem. Ital. Cens. Faun.: 123-130.

Möller D. 1967. Der nutzbare Zuwachs des Hasen in Abhangigkeit von regionalen Klimaunterschieden. Arch. Forstwes. 16: 929-932.

Monaghm P. and Metcalfe N. B. 1985. Group foraging in wild brown hares: effects of resource distribution and social status. Anim. Behav. 33: 993-999.

Neu C. W., Byers C. R. and Peek J. M. 1974. A technique for analysis of utilization availability data. J. Wildl. Manage. 38: $541-545$.

Overton W. 1971. Estimating the numbers of animals in wildlife populations [In: Wildlife management techniques, R. H. Giles, ed.]. The Wildlife Society, Washington D. C.: 403-455.

Pepin D. 1978. Structure de populations de liêvres en automne dans diffêrent agrosystêmes. Ann. Zool. Ecol. Anim. 10: 97-112.

Pepin D. and Birkan M. 1981. Comparative total- and strip-census estimates of hares and partridges. Acta Oecologica, Oecol. Applic. 2: 151-160.

Prigioni C. and Pelizza S. (in print) Habitat use by the European hare (Lepus europaeus) in agricultural areas of Northern Italy. XVIIIth I.U.G.B. Congress, Kraków, Poland.

Prigioni C. and Pelizza S. 1988. Produttivita della Lepre (Lepus europaeus) in aree protette della provincia di Pavia. I Convegno Nazionale dei Biologi della Selvaggina, Bologna: 263-270.

Puppe K. 1966. Untersuchungen über die Variationsbreite des nutzbaren Zuwachses des Hasen in Abhängigheit von regionalen klimaunterschieden. Beitr. Jagd-und. Wildforsch. 5, Tag.-Ber. dt. Akad. Landwirtsch.-Wiss. 90: 109-117.

Rajska E. 1968. Estimation of European hare population density depending on the width of the assessment belt. Acta theriol. 23: 35-53.

Smith T. D. 1981. Line-transect techniques for estimating density of porpoise schools. J. Wildl. Manage. 45: $650-657$.

Spittler H. 1976. Witterungsfaktoren als Grundlage für Vorhersagne über die Entwicklung des Hasenbesatzes. [In: Ecology and management of European hare populations, Z. Pielowski and Z. Pucek, eds]. Warszawa: $115-118$.

Swihart R. K. 1986. Home range-body mass allometry in rabbits and hares (Leporidae). Acta theriol. 31: $139-148$.

Tapper S. C. and Barnes R. F. 1986. Influence of farming practice on the ecology of the Brown hare (Lepus europaeus). J. Appl. Ecol. 23: 39-52.

Received 26 January 1989, accepted 11 October 1989. 